\title{
Aqueous root extract of Chrysophyllum albidum caused dose and duration dependent increases in some reproductive hormones and spermatogenic arrest in the testes of male Wistar rats
}

\author{
Eseohe V. Oigbochie ${ }^{1}$, Kingsley Omage ${ }^{2^{*}}$ (i) and Enoghense D. Odiase ${ }^{1}$
}

\begin{abstract}
Background aim: In ethnomedicine, different parts of Chrysophyllum albidum have been used as herbal remedies for the treatment and management of various ailments. This study was carried out to determine the dose and duration dependent effects of administration of aqueous root extracts of Chrysophyllum albidum on the serum concentrations of some reproductive hormones and testes of the experimental rats.

Methods: Forty-five adult male Wistar rats were used for this study. They were randomized into 3 groups (groups 1,2 \& 3) of 15 rats each, with each group further randomized into 3 subgroups (subgroups 1a, 1b, 1c; 2a, 2b, 2c; 3a, $3 b, 3 c)$ of 5 rats each, according to the dose and duration of extract administration.

Results: At the 8th week of extract administration, there were significantly $(P<0.05)$ higher concentrations of FSH in the treated subgroups while at weeks 6 and 8 , there were significant $(p<0.05)$ increases in the serum concentrations of $\mathrm{LH}$ of the treated subgroups as compared to those of the control subgroups. Also, at weeks 6 and 8 , administration of the extract resulted in significant $(P<0.05)$ increases in the concentrations of serum testosterone in the treated subgroups. Photomicrograph of the testes revealed focal spermatogenic arrest in the area biopsied in the treated subgroups (with low and high doses) at weeks 6 and 8 of extract administration.

Conclusion: The administration of aqueous root extract of Chrysophyllum albidum to male Wistar rats at increasing doses and time duration may affect their fertility and calls for caution in the prolonged use of the plant in folk medicine.
\end{abstract}

Keywords: Chrysophyllum albidium, Aqueous root extract, FSH, LH, Testosterone, Testes

\section{Introduction}

From time immemorial medicinal plants have been used in all cultures as a source of medicine [1]. Over 5000 plants have been used for medicinal purposes in Africa [2]. Medicinal plants are herbal remedies that are used for the treatment and management of ailments, and there exclusive use has served as one of the most vital approach accessible to man [3]. It is generally known that the

\footnotetext{
* Correspondence: omagekingsley@yahoo.com

${ }^{2}$ Department of Biochemistry, College of Basic Medical Sciences, Igbinedion University, Okada, Edo State, Nigeria

Full list of author information is available at the end of the article
}

consumption of a variety of local herbs and vegetables by man has contributed significantly to the improvement of his health, in terms of prevention, and or cure of diseases [1]. Although useful therapeutically, the prolonged usage of these herbs without proper evaluation has brought about a number of health related problems like infertility, a common problem which affects many couples all over the world [4].

Chrysophyllum albidum is an indigenous plant and an edible tropical fruit. It is a medicinal herb which belongs to the family Sapotaceae. Phytochemistry of Chrysophyllum albidum stem slash, seed cotyledon, leaves and root 
[5], revealed the presence of alkaloids, tannins, phenols and flavonoids; except cardiac glycosides in the root; tannins in leaves; and phenol in seed. Also, studies [6] on the antimicrobial effect of Chrysophillum albidum leave extract on gastrointestinal tract pathogenic bacteria and fungi in humans showed that the leaf extract has a broad spectrum antibiotic activities. It has been recommended that Chrysophyllum albidum could be employed as sources of natural antioxidant boosters for the treatment of free radical implicated oxidative stress disorders [7].

As the use of different parts of Chrysophyllum albidum as herbal treatment increases, it is necessary to evaluate the effects of the aqueous extract of the plant on some male reproductive hormones and their testes, so as to ascertain its possible dose and duration dependent effects.

\section{Materials and methods}

\section{Plant material and extract preparation}

Chrysophyllum albidum root bark was obtained from a local garden within Benin City and authenticated by a plant taxonomist in the Department Of Plant Biology And Biotechnology, University Of Benin. The bark was properly washed, air dried and oven dried. The dried bark was then ground into fine powder using a mechanical grinder and weighed. About $800 \mathrm{~g}$ of the powder was macerated with $1.5 \mathrm{l}$ of distilled water for $24 \mathrm{~h}$, with continuous stirring and shaking using a magnetic stirrer. The mixture was then filtered using Whatman No 1 filter paper and the filtrate concentrated using a rotary evaporator (BUCHI, type RE111, Rotavapor).

\section{Experimental animals}

Forty-five (45) adult male Wistar rats weighing between $200 \mathrm{~g}$ and $250 \mathrm{~g}$ used for the experiment were housed in the animal house of the Department of Anatomy, University of Benin, Benin City. The rats were allowed to acclimatize to the animal house for two weeks and they had free access to feed (growers mash from Bendel Feed Flour Mill Ltd) and water. The rats were maintained a on a $12 \mathrm{~h}$ light and dark cycle and cared for in accordance with the guidelines of the Research Ethics Committee of the College of Medical Sciences, University of Benin, Benin City.

\section{Experimental design}

The experimental animals were randomized into 3 groups of 15 rats each and treated as follows;

Group 1: The rats in this group served as control and were given normal diet and distilled water.

Group 2: Aqueous extract of Chrysophyllum albidum was administered orally at $250 \mathrm{mg} / \mathrm{kg}$ (Low Dose) to the rats in this group.
Group 3: Aqueous extract of Chrysophyllum albidum was administered orally at $500 \mathrm{mg} / \mathrm{kg}$ (High Dose) to the rats in this group.

Each group was further subdivided (randomized) into 3 subgroups, with 5 rats each, according to the duration of administration of the extract as follows;

\section{Grouping of experimental rats according to dose and duration of administration of extract}

\begin{tabular}{|c|c|c|c|c|c|c|c|c|c|}
\hline \multirow{2}{*}{$\begin{array}{l}\text { MAIN } \\
\text { GROUPS }\end{array}$} & \multicolumn{3}{|c|}{ CONTROL } & \multicolumn{3}{|c|}{ LOW DOSE (LD) } & \multicolumn{3}{|c|}{ HIGH DOSE (HD) } \\
\hline & 1 & & & 2 & & & 3 & & \\
\hline \multirow{2}{*}{$\begin{array}{l}\text { SUB } \\
\text { GROUPS }\end{array}$} & $1 a$ & $1 b$ & $1 c$ & $2 \mathrm{a}$ & $2 b$ & $2 c$ & $3 a$ & $3 b$ & $3 c$ \\
\hline & $\begin{array}{l}4 \\
\text { wks }\end{array}$ & $\begin{array}{l}6 \\
\text { wks }\end{array}$ & $\begin{array}{l}8 \\
\text { wks }\end{array}$ & $\begin{array}{l}4 \\
\text { wks }\end{array}$ & $\begin{array}{l}6 \\
\text { wks }\end{array}$ & $\begin{array}{l}8 \\
w k s\end{array}$ & $\begin{array}{l}4 \\
\text { wks }\end{array}$ & $\begin{array}{l}6 \\
\text { wks }\end{array}$ & $8 w k s$ \\
\hline
\end{tabular}

\section{Body weight and organ weight measurements}

The body weights of the rats were taken weekly while their organ weights were taken at the end of the experiment (after sacrifice) using a Top loader weighing balance.

\section{Determination of $\mathrm{LD}_{50}$}

The $\mathrm{LD}_{50}$ of Chrysophyllum albidum root bark as determined by Adewoye et al. (2010) [8] is $1850 \mathrm{mg} / \mathrm{kg}$ body weight.

\section{Extract administration and duration}

The extract was administered orally and daily using an orogastric tube. Subgroups 1a, 2a and 3a were given extract for 4 weeks, subgroups $1 \mathrm{~b}, 2 \mathrm{~b}$, and $3 \mathrm{~b}$ for 6 weeks, while $1 \mathrm{c}, 2 \mathrm{c}$ and $3 \mathrm{c}$ were given extract for 8 weeks.

\section{Sacrifice of animals}

At the end of each experimental period (i.e. at week 4, week 6 and week 8), a transverse incision was made through the ventral wall of the abdomen of each rat under slight chloroform anaesthesia. The testes were excised and fixed in Bouin's fluid in readiness for routine histological procedure. Blood samples were also obtained from the descending abdominal aorta and homogenized in a plain bottle for hormonal assay estimation.

\section{Biochemical assay}

\section{Serum testosterone assay}

Serum Testosterone was assayed from blood obtained from descending abdominal aorta. The samples were assayed in batches from a standardized curve using the enzyme linked immunosorbent assay (ELISA) method [9]. The microwell kits used were from Syntro Bioresearch Inc., California USA. 


\section{RIGHT TESTES}

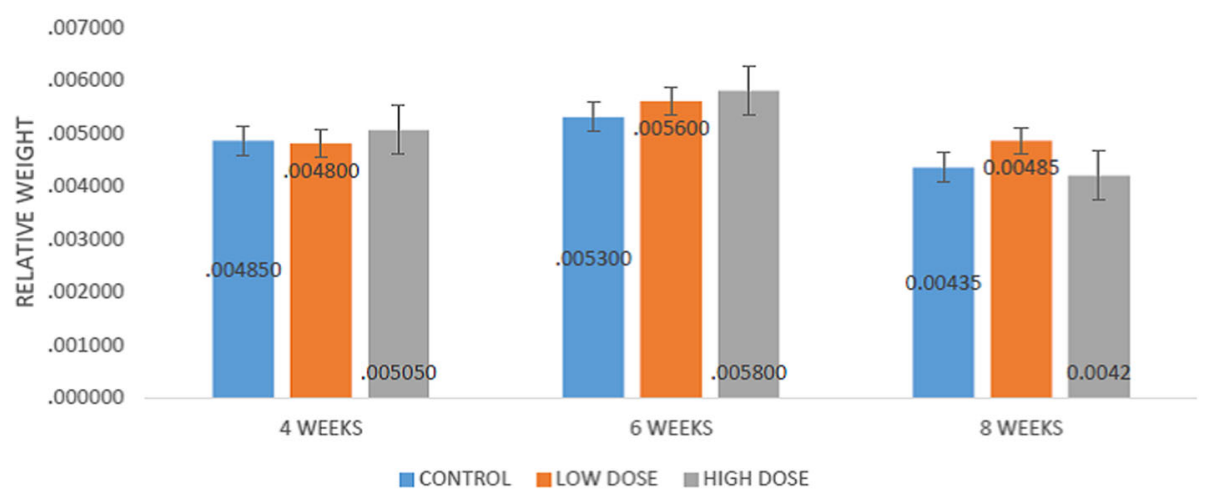

Fig. 1 Effect of administration of aqueous root extract of Chrysophyllum albidum on the weight of the right testes of the experimental rats. $n=5$

\section{Luteinizing hormone assay}

The BioCheck LH ELISA is based on the principle of a solid phase enzyme-linked immunosorbent assay [9]. The assay system utilizes sheep polyclonal anti-LH for solid phase (microtiter wells) immobilization, and a mouse monoclonal anti-LH in the antibody enzyme (horseradish peroxidase) conjugate solution.

\section{Follicle stimulating hormone assay}

This assay was carried out using double antibody radio immuno-assay. A rat recombinant FSH $\{1125\}$ from Amersham, UK was used. The sensitivity of the assay was $0.9 \mathrm{ng} / \mathrm{ml}[9]$.

\section{Histological procedure}

The tissues were fixed in Bouin's fluid for less than $24 \mathrm{~h}$. The tissues were then processed via paraffin wax embed method of Drury and Wallington (1980) [10] and Scheehan and Brapchak (1980) [11].

\section{HAEMATOXYLIN and eosin staining method}

Staining of the tissues was done using $\mathrm{H}$ \& $\mathrm{E}$ dyes (Haematoxylin and Eosin dyes).

\section{Photomicrography}

The sections were examined under a Leica DM750 research microscope with a digital camera Leica ICC50 attached. Digital photomicrographs of the tissues section were taken at various magnifications.

\section{Statistical analysis}

The data generated were analyzed using descriptive and inferential statistics. Data were presented as Mean \pm Standard Error of Means (S.E.M). Significance difference of means was determined using one-way analysis of variance (ANOVA) at 95\% confidence interval. Least Square Difference (LSD) and post-hoc tests were carried out for all groups. All statistical analysis was carried out using Statistical Package for Social Sciences (SPSS) (version 17) manufactured by International Business Machine Corporation (IBM) in Armonk, New York.

\section{LEFT TESTES}

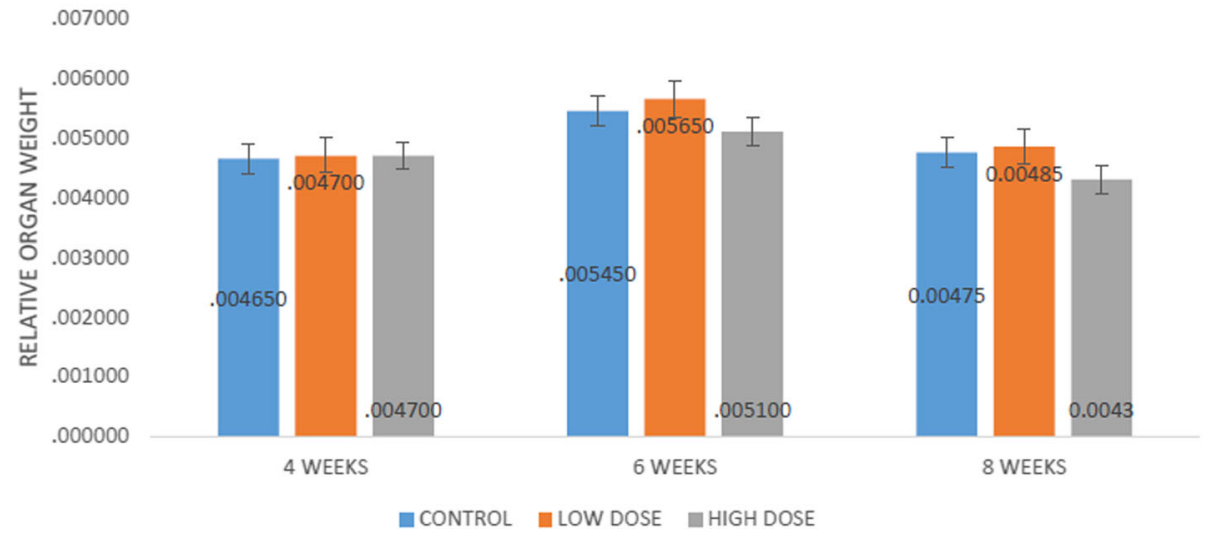

Fig. 2 Effect of administration of aqueous root extract of Chrysophyllum albidum on the weight of the left testes of the experimental rats. $n=5$ 


\section{Follicle Stimuting Hormone}

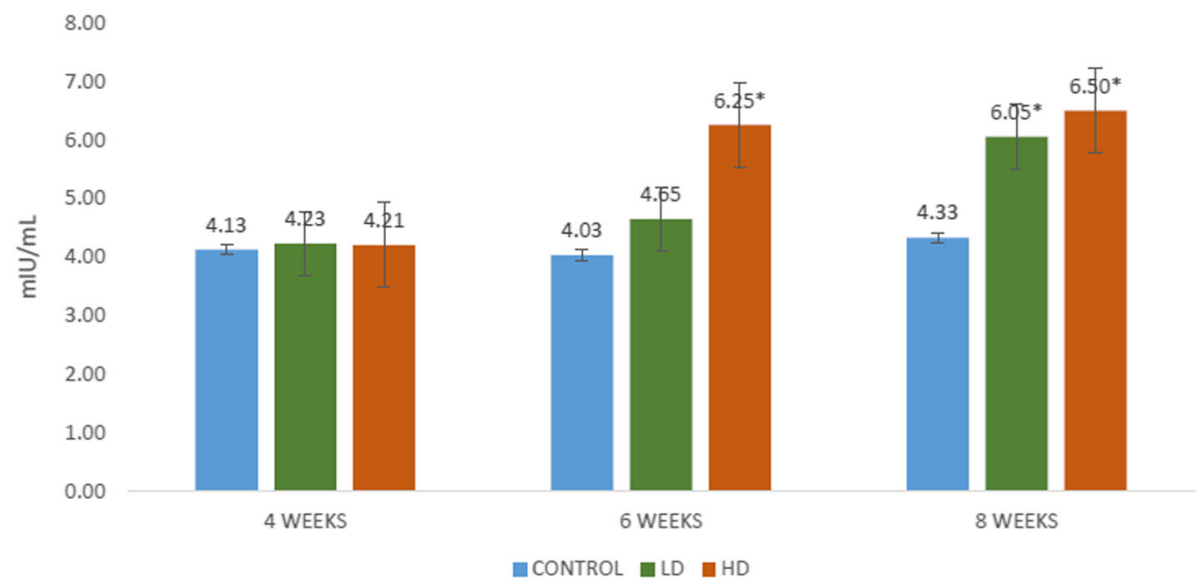

Fig. 3 Effect of aqueous root extract of Chrysophyllum albidium on serum concentration of follicle stimulating hormone (FSH) of the experimental rats. Bars represent Mean \pm SEM. $n=5$. * superscript shows Mean with significant $(P<0.05)$ difference within each week

\section{Results}

The effects of administration of aqueous root extracts of Chrysophyllum albidum on the organ weights, serum concentrations of Follicle Stimulating Hormone (FSH), Luteinizing Hormone (LH), Testosterone and histology of the testes of the experimental rats are as shown below.

\section{Effect on weight of testes}

In Figs. 1 \& 2, administration of the aqueous root extract of Chrysophyllum albidum did not cause any significant changes $(p>0.05)$ in the weight of the organs (left testes and right testes) of rats in the treated groups (or subgroups) as compared with the control groups (or subgroups), in the 4th, 6th and 8th week of the experiment.

\section{Effect on serum concentration of follicle stimulating hormone (FSH)}

At the 4th week of extract administration, there were no observed significant $(P>0.05)$ differences in the serum concentrations of FSH of all the groups (1a, 2a $\& 3 a)$. At the 6th week, the concentration of FSH of the subgroup $3 \mathrm{~b}$ (given high dose) was significantly $(p<0.05)$ higher than those of the control subgroup (1b) and subgroup $2 \mathrm{~b}$ (given low dose). At the 8th week of extract administration, there were significantly $(P<0.05)$ higher

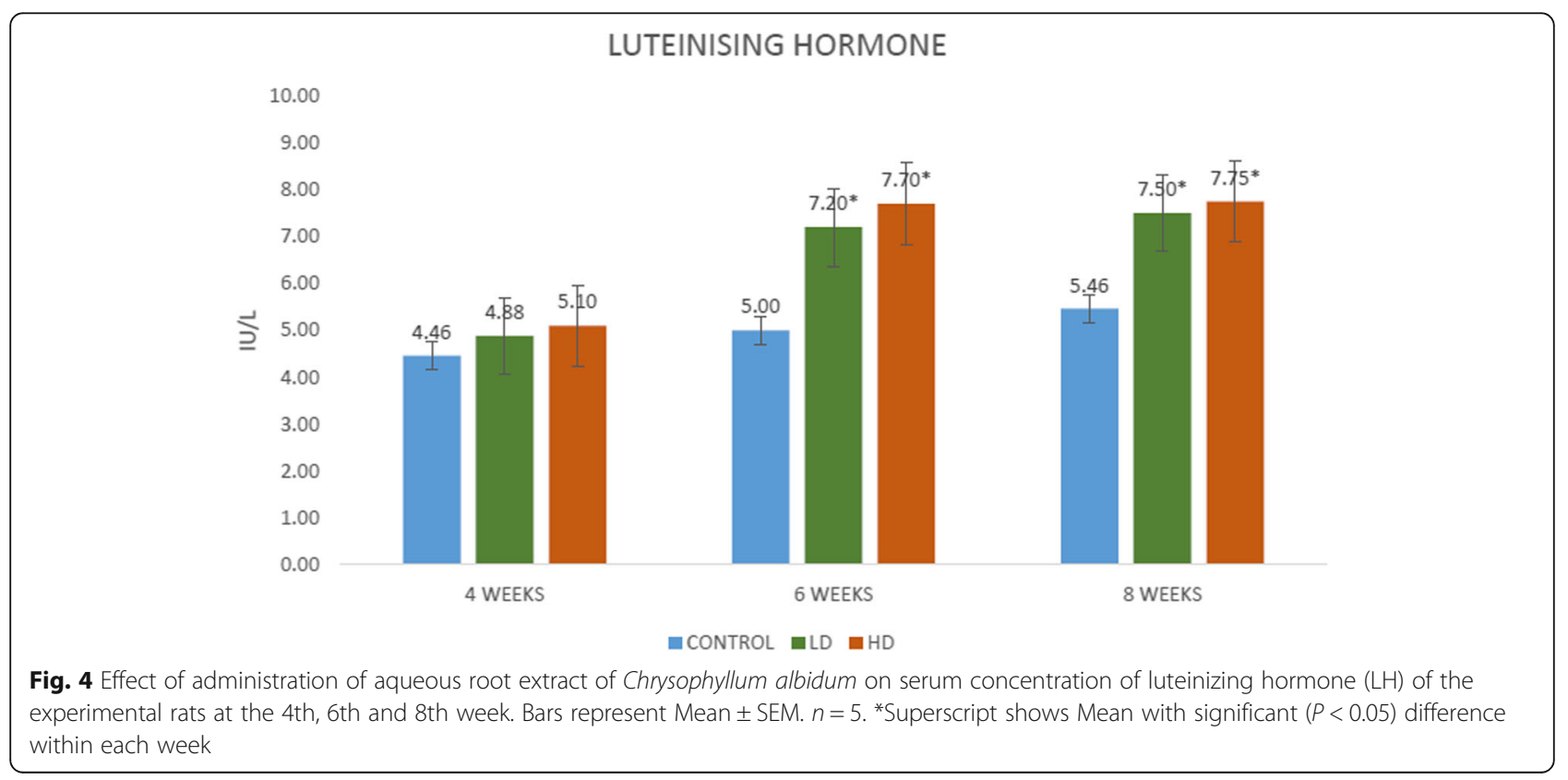




\section{TESTOSTERONE}

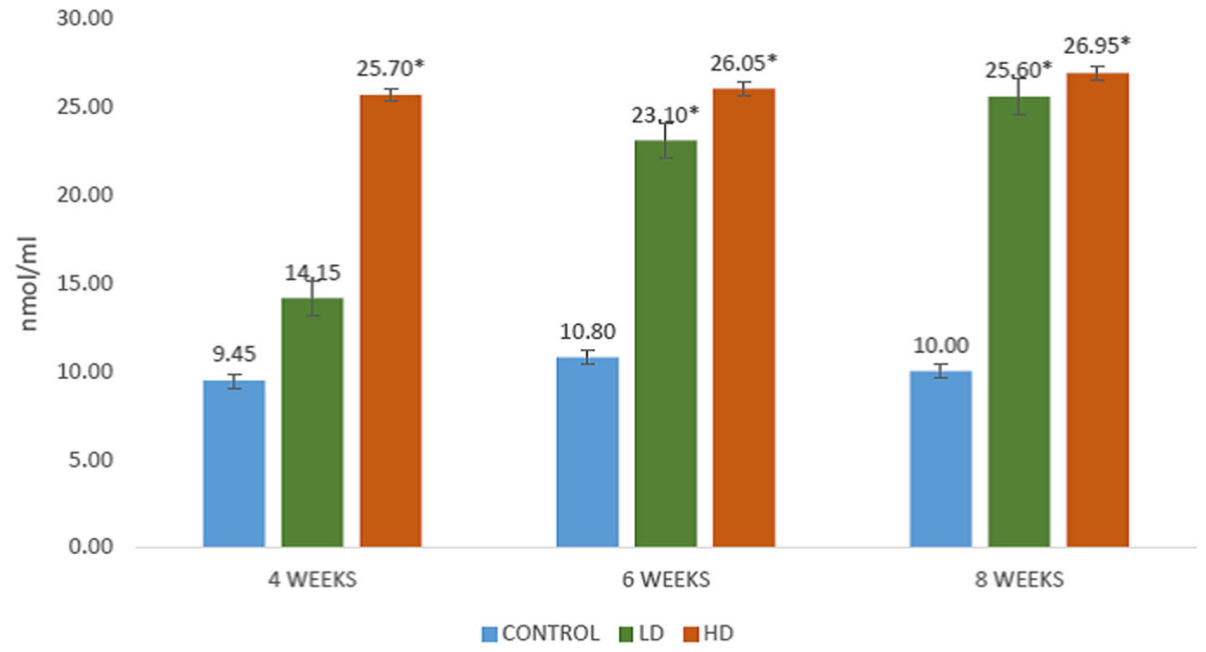

Fig. 5 Effect of administration of aqueous root extract of Chrysophyllum albidum on serum concentration of testosterone of the experimental rats at the 4 th, 6 th and 8 th week of the experiment. Bars represent Mean \pm SEM. $n=5$. *Superscript shows Mean with significant $(P<0.05)$ difference within each week
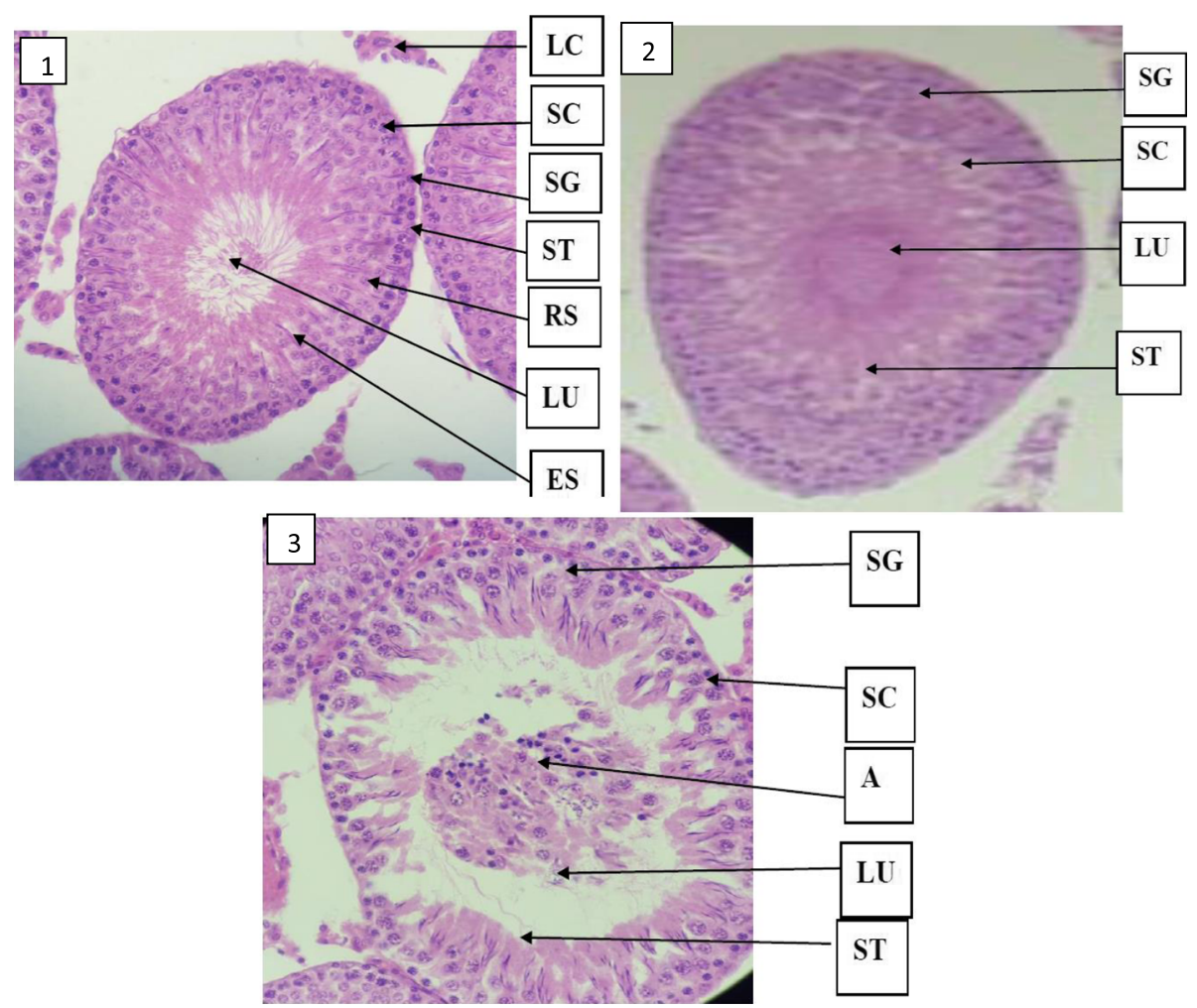

Fig. 6 Photomicrograph of histological sections of the testes of the experimental rats at week 4. H \& E × 400. Plate 1; Control subgroup (1a). Sectioned area showing Interstitial cells of Leydig in the interstitial space (LC); Seminiferous tubule epithelium containing cells of the spermatogenic series including spermatogonia (SZ); spermatocyte (SC); Round spermatids (RS); elongated spermatids (ES) and sertoli cells and the lumen containing spermatozoa (LU). Plate 2: Treated subgroup (2a) with $250 \mathrm{mg} / \mathrm{kg}$ body weight of aqueous root extract of Chrysophyllum albidum. Sectioned area shows spermatogenic cells in normal sequential maturation. Plate 3: Treated subgroup (3a) with $500 \mathrm{mg} / \mathrm{kg}$ body weight of aqueous root extract of Chrysophyllum albidum. Sectioned area shows focal spermatogenic arrest at the stage of conversion from spermatocyte to spermatids (A). Spermatogenic cells in view include spermatogonia (SG); spermatocyte (SC). The lumen contains admixture of immature cells of the spermatogenic series (LU) 
concentrations of FSH in the treated subgroups $(2 \mathrm{c} \& 3 \mathrm{c})$ as compared with the control subgroup (1c). (Fig. 3).

\section{Effect on serum concentration of LUTEINISING hormone (LH)}

In Fig. 4, after 4 weeks of extract administration, there were no significant $(P>0.05)$ differences in the serum concentrations of the LH of the treated subgroups (2a \& 3a) as compared to that of control subgroup (1a). However, administration of the extract for 6 and 8 weeks resulted in significant $(p<0.05)$ increases in the serum concentrations of LH of the treated subgroups (2b \& $3 \mathrm{~b} ; 2 \mathrm{c} \& 3 \mathrm{c}$ ) as compared to those of the control subgroups $(1 \mathrm{~b} ; 1 \mathrm{c})$.

\section{Effect on serum concentration of testosterone (t)}

Figure 5; after 4 weeks of extract administration, no significant difference $(P>0.05)$ was observed in the serum concentrations of testosterone between the subgroup treated with low dose (2a) and the control subgroup (1a), but there was a significant $(p<0.05)$ increase in subgroup 3a treated with high dose of the extract, comparatively. At the 6th and 8th weeks, administration of the extract resulted in significant $(P<0.05)$ increases in the concentrations of serum testosterone in the treated subgroups (2b, 2c \& 3b, 3c) as compared to the control subgroups $(1 \mathrm{~b}, 1 \mathrm{c})$.

\section{Effect on histology of testes}

In Figs. 6, 7 \& 8, photomicrograph of histological sections of the testes of the experimental rats revealed that there was no histological difference between the subgroup (2a) treated with low dose of aqueous root extract of Chrysophyllum albidum in the 4th week, but the subgroup (3a) treated with high dose show focal areas of spermatogenic arrest. At weeks 6 and 8 of the extract administration, photomicrograph of the testes revealed gradual increased focal spermatogenic arrest in the area biopsied in both treated subgroups (low and high doses).

\section{Discussion}

This study focused on the dose and duration effects of aqueous root extract of Chrysophyllum albidum on some reproductive hormones and histology of the testes of the experimental rats. However, administration of the extract at the different doses and time duration under study did not cause any significant changes in the organ

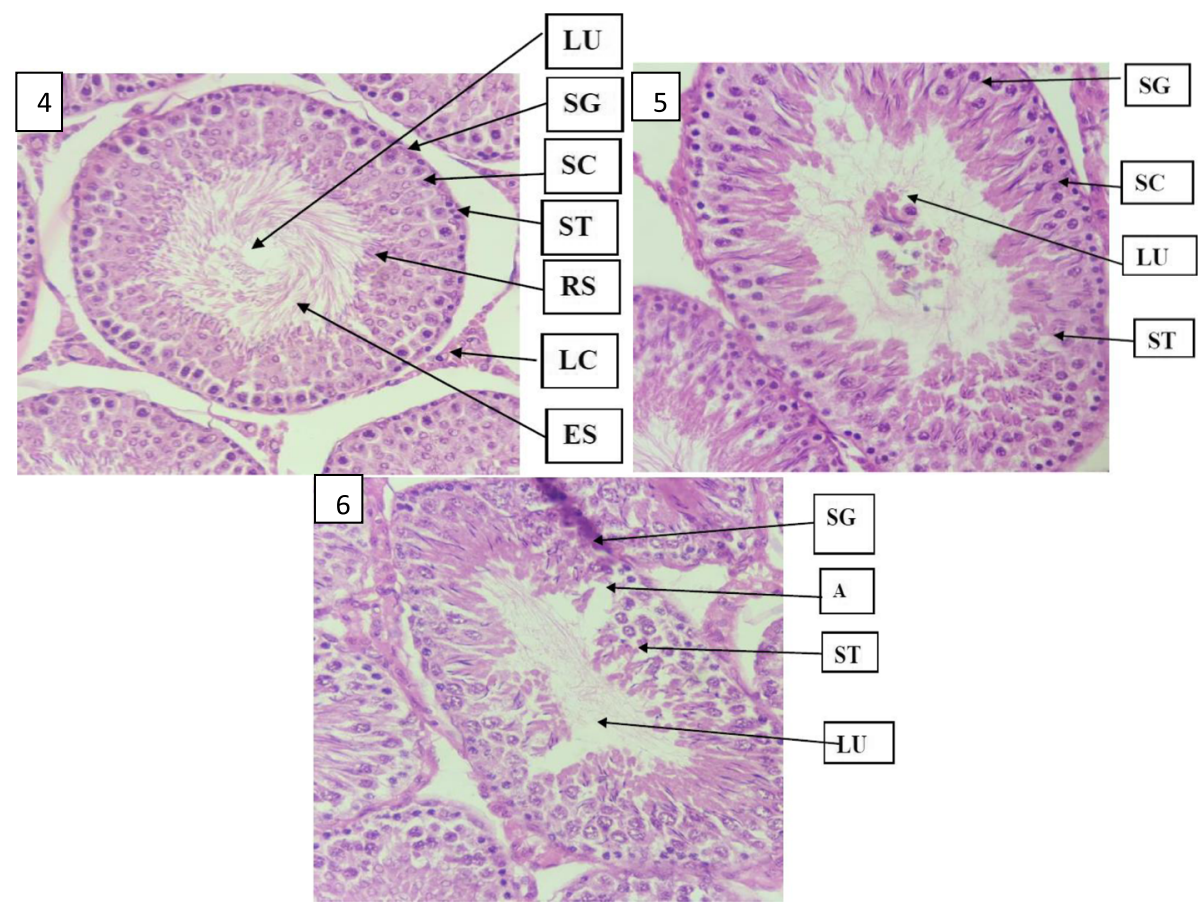

Fig. 7 Photomicrograph of histological sections of the testes of the experimental rats at week 6 . H \& E $\times 400$. Plate 4: Control subgroup (1b). Interstitial cells of Leydig in the interstitial space (LC); Seminiferous tubule epithelium containing cells of the spermatogenic series including spermatogonia (SZ); spermatocyte (SC); Round spermatids (RS); elongated spermatids (ES) and sertoli cells and the lumen containing spermatozoa(LU). Plate 5: Treated subgroup (2b) with $250 \mathrm{mg} / \mathrm{kg}$ body weight of aqueous root extract of Chrysophyllum albidum. Spermatogenic arrest at the stage of conversion from spermatocyte to spermatids. Spermatogenic cells in view include spermatogonia (SG); spermatocyte (SC). The lumen contains admixture of immature cells of the spermatogenic series (LU). Plate 6: Treated subgroup (3b) with $500 \mathrm{mg} / \mathrm{kg}$ body weight of aqueous root extract of Chrysophyllum albidum. Sectioned area showing Focal Spermatogenic arrest (A) 


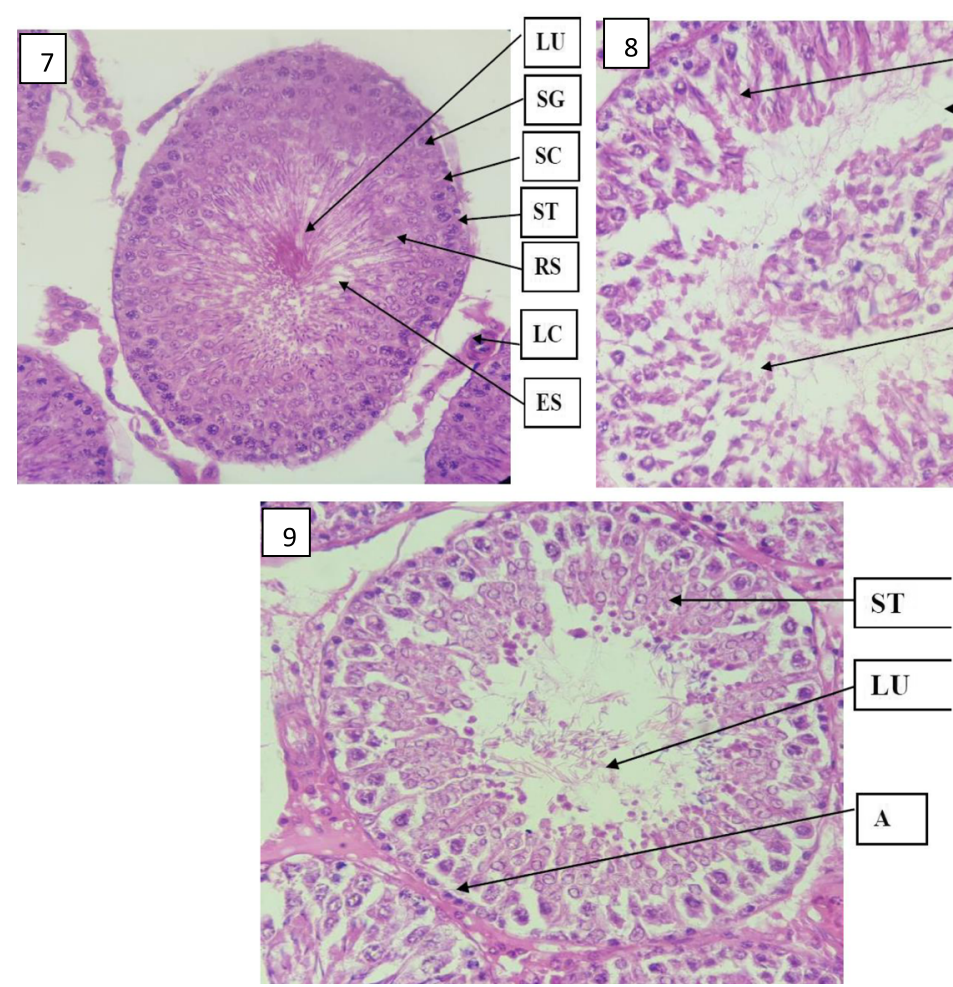

Fig. 8 Photomicrograph of histological sections of the testes of the experimental rats at week 8 . H \& E × 400. Plate 7: Control subgroup (1c). Interstitial cells of Leydig in the interstitial space (LC); Seminiferous tubule epithelium containing cells of the spermatogenic series including spermatogonia (SZ); spermatocyte (SC); Round spermatids (RS); elongated spermatids (ES) and sertoli cells and the lumen containing spermatozoa(LU). Plate 8: Treated subgroup (2c) with $250 \mathrm{mg} / \mathrm{kg}$ body weight of aqueous root extract of Chrysophyllum albidum. Showing, spermatogenic arrest (A) presence of immature cells in the lumen of the seminiferous tubule (ST). Plate 9: Treated subgroup (3C) with $500 \mathrm{mg} / \mathrm{kg}$ body weight of aqueous root extract of Chrysophyllum albidum. Showing, focal spermatogenic arrest (A) presence of immature cells in the lumen of the seminiferous tubule (ST)

(testes) weights of the rats in all the treated subgroups as compared to the control subgroups. This likely shows that the extract did not considerably, affect the normal metabolic processes (specifically nutrient metabolism) of the experimental rats. Although, it is possible that most of the nutrients were channeled into the production of hormones and sperm cells through the spermiogenetic process, thus affecting the availability of nutrients for storage or buildup of tissues in the testes.

Production of nutrients and androgen-binding protein $(\mathrm{ABP})$, which concentrates testosterone to a level required for spermiogenesis, is promoted by follicle-stimulating hormone (FSH). As endocrine cells, they secrete the 39-kDa glycoprotein inhibin, which feeds back on the anterior pituitary gland to suppress FSH synthesis and release. Elevated serum FSH is a reliable indicator of germinal epithelial damage [12]. It was observed that the administration of the aqueous root extract of Chrysophyllum albidum resulted in dose and duration dependent corresponding increases in the serum concentrations of FSH of the rats in all the treated subgroups. Although increased levels of FSH have been measured in men with arrest at the level of primary spermatocyte [13], this may point to a likely adverse effect of the extract with consequent germinal epithelial damage. A damaged germinal epithelium, possibly occasioned by the administration of the aqueous extract of Chrysophyllum albidum, could bring about the production of defective sperm cells as observed in the histology of the testes. Also, as observed, the serum concentrations of LH and Testosterone increased significantly with respect to increasing doses and duration of administration of the extract. These increases can be related to feedback mechanisms in response to changes in the testes caused by the administration of the extract. The increased testosterone levels in the experimental animals may increase the frequency of copulation but with consequent ejaculation of defective sperm cells, thus affecting their fertility negatively.

Spermatogenic arrest, an interruption of the complex process of germ cell differentiation which leads to the formation of spermatozoa [14], increased in the testes of the treated rats as observed in the area biopsied. Histological findings revealed gradual increased focal spermatogenic arrest in the area biopsied in the subgroups given low dose of the extract, while all the 
treated subgroups with high doses of the extract show focal areas of spermatogenic arrest. Thus, administration of aqueous root extract of Chrysophyllum albidum at graded doses gradually induces arrest in spermatogenesis over a long period of time. The effects (i.e. spermatogenic arrests) tend to increase with increasing dose and duration of the extract administration. These effects could affect the fertility of the experimental rats, and calls for serious concern in the prolong use of the root of Chrysophyllum albidum in folk medicine.

\section{Conclusion}

The administration of aqueous root extract of Chrysophyllum albidum to male Wistar rats at different (increasing) doses and time (increasing) duration resulted in increases in serum concentrations of FSH, LH and Testosterone, as well as arrest of spermatogenesis in their testes. This may affect their fertility and calls for caution in the prolong use of the plant in folk medicine.

\begin{abstract}
Abbreviations
ABP: Androgen-binding Protein; ES: Elongated Spermatids; FSH: Follicle Stimulating Hormone; LH: Luteinizing Hormone; RS: Round Spermatids; SC: Spermatocyte; SG: Spermatogonia; ST: Seminiferous Tubules
\end{abstract}

\section{Acknowledgements}

The Authors acknowledge the Department of Anatomy, School of Basic Medical Sciences, College of Medical Sciences, University of Benin, (Edo State, Nigeria) for providing the necessary laboratory facilities.

Availability of data and materials

Not applicable.

\section{Authors contributions}

EVO conceived and designed the experiments; EDO performed the experiments and analyzed the data; while KO wrote the paper. All authors read and approved the final manuscript.

Authors's information

Not applicable.

Ethics approval and consent to participate

The procedures and protocols of the study were approved by the Research Ethics Committee of the College of Medical Sciences, University of Benin, Benin City.

\section{Consent for publication}

Not applicable.

\section{Competing interest}

The authors wish to state that there are no competing interests associated with this publication and there has been no significant financial support for this work that could have influenced its outcome.

\section{Publisher's Note}

Springer Nature remains neutral with regard to jurisdictional claims in published maps and institutional affiliations.

\section{Author details}

'Department of Anatomy, School of Basic Medical Sciences, College of Medical Sciences, University of Benin, Benin City, Edo State, Nigeria. ${ }^{2}$ Department of Biochemistry, College of Basic Medical Sciences, Igbinedion University, Okada, Edo State, Nigeria.
Received: 12 December 2017 Accepted: 20 December 2018

Published online: 08 January 2019

References

1. Chevallier A. Encyclopedia of medicinal plants. New York, NY: DK Publishing. 1996, 237.

2. Taylor JLS, Rabe T, McGaw L, Jäger AK, van Staden J. Towards the scientific validation of traditional medicinal plants. Plant Growth Regul. 2001;34:23-37.

3. Eze KN. Antifertility Effects Of Ethanolic Extract Of Xylopia aethiopica On Male Reproductive Organ Of Wistar Rats. American Journal Of Medicine And Medical. Sciences. 2012:2(1):12-5.

4. Leke R. Reproductive health in Cameroon. Geneva, WHO. collaborating centre for Research in Human Reproduction 2008.

5. Okoli BJ, Okere OS. Antimicrobial Activity of the Phytochemical Constituents of Chrysophyllum albidum G.Don Holl. (African Star apple). Plant. Journal of Research in National. Development. 2010;8(1):11-16.

6. Ajetunmobi AO, Phytochemical Analysis TGA. Antimicrobial Effect of Chrysophillum Albidum Leave Extract On Gastrointestinal Tract Pathogenic Bacteria and Fungi in Human. IOSR J Appl Chem. 2014;2(1):1-5.

7. Adebayo AH, Abolaji AO, Kela R, Ayepola OO, Olorunfemi TB, Taiwo OS Antioxidant activities of the leaves of Chrysophyllum albidum. Pak J Pharmacetical Sci. 2011:24(4):545-51.

8. Adewoye EO, Salami AT, Taiwo VO. Anti-plasmodial and toxicological effects of methanolic bark extract of Chrysophyllum albidum in albino mice. J Physiol Pathphysiology. 2001;1(1):1-9.

9. Tietz NW. Clinical Guide to Laboratory Tests. 3rd ed. Philadelphia, USA: W.B. Saunders Company; 1995. p. 578-80.

10. Drury RA, Wallington EA. Cartelon's Histological Techniques. Oxford University Press: 1980; 5: 195

11. Sheehan DC, Hrapchak BB. Theory and practice of histotechnology. 2nd Edition, The CV Mosby Company, St Louis. MO: C. V. Mosby Co. 1980; 143-144.

12. Carvalhal S, Stevense M, Koehler K, Naumann R, Huebner A, Jessberger R. Griffis ER. ALADIN is required for the production of fertile mouse oocytes. Mol Biol Cell. 2017:28(19):2470-8

13. Tesarik J, Balaban B, Isiklar A, Alatas C, Urman B, Aksoy S, Mendoza C, Greco E. In-vitro spermatogenesis resumption in men with maturation arrest: relationship with in-vivo blocking stage and serum FSH. Hum Reprod. 2000; 15(6):1350-4.

14. Rastegar T, Habibi RM, Parvari S, Baazm M. The interaction between Sertoli cells and luekemia inhibitory factor on the propagation and differentiation of spermatogonial stem cells in vitro. Iran J Reprod Med. 2015;13(11):679-86

\section{Submit your manuscript to a SpringerOpen ${ }^{\circ}$ journal and benefit from:}

- Convenient online submission

- Rigorous peer review

- Open access: articles freely available online

- High visibility within the field

- Retaining the copyright to your article

Submit your next manuscript at $\boldsymbol{\nabla}$ springeropen.com 